\title{
Antoinette et Jean Ehrard, Brutus à la scène: autour du décret du 2 aout 1793
}

\section{Franco Piva}

\section{(2) OpenEdition}

1 Journals

\section{Édition électronique}

URL : http://journals.openedition.org/studifrancesi/36118

DOI : 10.4000/studifrancesi.36118

ISSN : 2421-5856

Éditeur

Rosenberg \& Sellier

\section{Édition imprimée}

Date de publication : 1 juillet 2005

Pagination : 161-162

ISSN : 0039-2944

\section{Référence électronique}

Franco Piva, «Antoinette et Jean Ehrard, Brutus à la scène: autour du décret du 2 aout 1793 », Studi Francesi [En ligne], 145 (XLIX | I) | 2005, mis en ligne le 30 novembre 2015, consulté le 20 avril 2021. URL : http://journals.openedition.org/studifrancesi/36118; DOI : https://doi.org/10.4000/ studifrancesi.36118

Ce document a été généré automatiquement le 20 avril 2021.

\section{(c) 9 (i) $\Theta$}

Studi Francesi è distribuita con Licenza Creative Commons Attribuzione - Non commerciale - Non opere derivate 4.0 Internazionale. 


\title{
Antoinette et Jean Ehrard, Brutus à la scène: autour du décret du 2 aout
} 1793

\author{
Franco Piva
}

\section{RÉFÉRENCE}

ANTOINETTE et JEAN EHRARD, avec la collaboration de FRANCOIS EHRARD, Brutus à la scène: autour du décret du 2 aout 1793, in Les arts de la scène \& la Révolution française. Sous la direction de PHILIPPE BOURDIN et GÉRARD LOUBINOUX, Clermond-Ferrand, Presse Universitaires Blaise-Pascal, Vizille, Museée de la Révolution française, 2004, pp. 293-311.

Les auteurs s'interrogent sur l'influence que le décret du 2 août 1793, obligeant certains théâtres de représenter «trois fois par semaine les tragédies républicaines telles que celles de Brutus, Guillaume Tell, Caius Gracchus et autres pièces dramatiques propres à entretenir les principes d'égalité et de liberté» a exercée sur la «fortune» de Brutus qui, comme chacun sait, a été une des figures symbole de la Révolution française. Après avoir constaté que la représentation de tragédies patriotiques reste fortement minoritaire même après le décret du 2 août (les grands succès sont remportés par les pièces légères, les Français, même les patriotes, vont au théâtre surtout pour s'amuser), les auteurs de cet article constatent toutefois non seulement que le Brutus de Voltaire continue après le 2 août 1793, la brillante carrière qu'il avait entamée en novembre 1790 même si ce succès tend un peu à faiblir suite au changement du climait politique, et que le personnage de Brutus apparait aussi par allusion dans plusieurs pièces qui ne lui sont pas consacrées, mais aussi (et c'est là la partie la plus intéressante et la plus originale de leur article) que Brutus «est souvent présent au théâtre d'une autre manière et sans même y être forcément nommé» précisant que "cette présence, aussi certaine qu'elle est diffuse, se décèle aisément dans l'un des thèmes privilégiés du théâtre de la Révolution: la discipline militaire», traité par maintes pièces, parmi 
lesquelles il y a certes les tragédies Manlius Torquatus ou la discipline romaine de Lavallée et Quintus Fabius ou la discipline romaine de Legouvé, mais aussi des pièces moins ambitieuses destinées à des théâtres plus légers. De sorte que «sous des costumes variés, en toge, en redingote ou sous l'habit bleu, voir en cotillon, Brutus n'a jamais vraiment quitté la scène»; une conclusion qui confirme et renforce les résultats auxquels est parvenu le Colloque Bruto il Maggiore nella letteratura francese (e dintorni) qui a eu lieu à Vérone en mai 2001 et auquel les auteurs de cet article ont apporté leur précieuse contribution. 